\title{
FURTHER TRAINING AND ADDITIONAL PROFESSIONAL EDUCATION OF SPECIALISTS AS PART OF A SYSTEM OF CONTINUOUS TRAINING FOR THE NEEDS OF THE ECONOMY
}

\author{
Anna Vorotyntseva ${ }^{1}$, Andrei Ovsiannikov ${ }^{2}$, Vladimir Bolgov ${ }^{3}$, Elena Ponomarenko ${ }^{4}$ \\ ${ }^{1}$ Candidate of Economics, Associate Professor, Voronezh State Technical University, \\ 20 years of October street, 84, Voronezh, Russia, E-mail: allslavin@mail.ru \\ ${ }^{2}$ Candidate of Economics, Associate Professor, Voronezh State Technical University, \\ 20 years of October street, 84, Voronezh, Russia, E-mail: ovsyannikovas@yandex.ru \\ ${ }^{3}$ Candidate of Economics, Associate Professor, Voronezh State Technical University, \\ 20 years of October street, 84, Voronezh, Russia, E-mail: v_bolgov@mail.ru \\ ${ }^{4}$ Senior Lecturer, Voronezh State Technical University, \\ 20 years of October street, 84, Voronezh, Russia, E-mail: enponomarenko@mail.ru
}

\begin{abstract}
The article describes the problems in the field of advanced training and additional professional education as part of a system of continuous training and retraining of specialists, taking into account the requirements of the current economic situation. Using the example of a higher educational institution: Voronezh State Technical University, we consider a system for organizing continuing professional education using digital technologies in teaching. The basis of the system of advanced training and retraining of personnel was reasonably chosen by a specialized faculty: the faculty of additional professional education. The problems that arise in the system of continuing professional education and retraining of personnel associated with a different level of training of specialists in the training flows are revealed, which are proposed to be solved with the help of educational interdisciplinary blocks and blocks of professional disciplines. Thanks to modern teaching methods based on the online format, it is possible to build a flexible system of continuing education for students of different qualifications and different basic levels of training.
\end{abstract}

Keywords: personnel for the economy, continuing professional education, advanced training, additional professional education, retraining of personnel, system.

\section{INTRODUCTION}

One of the main problems of the current state of various sectors of the economy of both the Russian Federation in particular and the global economy as a whole is the problem of the formation of personnel potential, the level of staff training and retraining. The current state of society is in constant transformation, which leads to a change in the system of vocational training and retraining. The system of continuing professional education (SCPE) involves the creation of a chain of institutions of primary, general, secondary and higher education, the inclusion in it of institutions of pre-university and extracurricular education, as well as educational institutions and centers involved in improving qualifications and retraining of personnel.

The system becomes continuous, it begins even in the school period, when it is connected with the system of early career guidance, which program "The Ticket for the Future" [1] is aimed at, and which is included, inter alia, within the framework of the national Education program and its composition of federal projects.

In the period of early career guidance, a contingent of applicants is formed who choose their profession for a reason, but based on knowledge of modern economic development trends, including on the basis of trends 
in the formation of STI markets. The help in choosing a future profession can be provided by studying the Atlas of New Professions, in the framework of which we study which professions will be in demand in the next 5.10, 15 and 20 years, and which will lose their relevance. [2] Although it should be noted that these forecasts are not always justified, but it's worth focusing on them.

\section{METHODOLOGY}

During the period of study at the university, the student is also included in the system of supplementary education, which runs in parallel with the main professional education and can be aimed at obtaining both basic (professional, rigid) competencies and interprofessional (supraprofessional, flexible) competencies. By the end of training at a university, a specialist may have the skill in several professional fields of activity, experience in the project team, as well as other competencies necessary for future work. Modern economic realities make it necessary for the so-called multispecialists to appear on the labor market, having deep professional knowledge in a certain field, but also having a certain level of knowledge in related fields [3].

But in the labor market there are many specialists who have already left the student age and received their basic professional education some time ago. [4]. It can be a year, five, ten, or more years. For them, a system of advanced training and additional professional education should be transformed, which has been actively developing in our country and abroad recently. [5-12].

\section{DISCUSSION}

This system does not develop from scratch, because on the basis of many universities there are departments, the main activity of which is precisely work in the area of professional additional retraining of modern personnel. [13]. Such a unit on the basis of the Voronezh State Technical University (Voronezh Support University) is the faculty of additional professional education. Further, the article will describe the experience of this unit in the framework of the SCPE. [14]. These experiences can be used by other educational institutions as a methodology (algorithm) for the development of similar units at its base. It should be noted that in Russia many universities are engaged in advanced training and additional professional education, so the authors of the article do not talk about their methodology as the only true.

It should be noted that one of the most progressive forms of the development of secondary vocational education is the improvement of the system of continuous multilevel vocational education, retraining and advanced training of scientific, engineering, technical and managerial personnel of enterprises, i.e. those workers who already take an active part in economic activity, but who have to improve and develop their knowledge and skills, taking into account already having professional skills and experience[15].

In modern conditions, it is necessary to give the educational system innovative characteristics that would contribute to improving the education system and raising the overall educational level. All this becomes even more relevant in connection with the development of digitalization systems, including the educational process, the emergence of a large number of online courses, which make it possible to acquire new knowledge in a remote format. It should be noted that this format makes continuing education more accessible. But not in all areas of preparation, it is possible to use such teaching methods, so we should not forget about traditional systems for obtaining knowledge - in the format of classroom lessons, including using modern technical means. [16].

Voronezh State Technical University has extensive experience in the work of the SCPE [17-18]. VSTU subsystem of additional education includes additional professional education:

1. on the basis of the faculty of additional professional education of VSTU,

2. on the basis of the departments of VSTU,

3. on the basis of the basic departments of GTU with the involvement of enterprises.

APE programs can be divided into 3 blocks: technical, construction and interdisciplinary.

VSTU Faculty of continuing professional education provides training in continuing education programs, professional retraining, holds information and consultation seminars. Training in an additional professional program is carried out on the basis of a training contract concluded with the student (individual / legal entity). Every year, more than 500 people undergo training at the faculty in various areas of training. Classes are conducted in the framework of full-time and part-time forms of training, including the use of distance technologies.

Training of specialists is carried out at the request of enterprises, as well as on the basis of individual 
agreements with students for the following main programs, included with the VSTU additional professional education system, including those that have been accredited and become the winner of the All-Russian media project in the field of additional professional education "Educational marathon -2016 ", which was carried out in order to popularize the best practices of the system of additional professional education implemented in the territory of the Russian Federation, to form a positive image of both the programs themselves and the issued qualification documents [19].

\section{RESULTS}

In 2019, FSPE VSTU filed an application for participation in the competitive selection of grants in the form of subsidies from the federal budget for the project "Training citizens in continuing education programs in educational organizations implementing additional educational programs and vocational training programs" of the federal project "New opportunities for everyone" of the national project "Education" in 2019" (selection code 2019-NVDK-02) [20]. In addition VSTU, as part of the grant support, implements the project "Safety of automobile roads", within the framework of which professional development of specialists is carried out in the following areas: "Construction safety and the quality of the construction of roads and airfields", "Construction safety and the quality of the construction of bridges, overpasses and overpasses" , "The safety of construction and the implementation of construction control", "Quality management system and the concept of lean manufacturing", "Pricing and budgeting."

The main tasks of the faculty of vocational education:

- Professional retraining and advanced training of specialists of organizations of various forms of ownership, civil servants, displaced and unemployed specialists, as well as the unemployed population;

- Provision of continuing education and development of the regional system of additional professional education;

- Assisting in the professional adaptation of specialists with no practical work experience;

- Cooperation with domestic and foreign companies, foundations and other interested organizations on the exchange of experience and the joint holding of conferences, congresses, seminars, meetings, training of listeners and employees of the University, internships, as well as joint scientific activities;

- Improving the quality of vocational education in accordance with promising areas of the labor market by involving the employer in the educational process;

- Development of the system through the development and implementation of modern educational programs and educational technologies.

The statistical analysis for 2017-2019 showed that during the period under review, interest in advanced training among specialists in various fields increases, the most interesting are the programs of continuing education, which relate to the interdisciplinary unit (Table 1). This suggests that enterprise specialists, possessing professional knowledge and skills in their main professional activity, under the influence of trends developed by modern economies want to get new professional competencies that are not directly related to their activities, but necessary for understanding teamwork and project activities

Table 1. Programs of the interdisciplinary block of additional professional education, training and retraining of personnel, implemented as part of the activity FSPE VSTU

\begin{tabular}{|l|l|}
\hline Year & SPE program \\
\hline 2018 & $\begin{array}{l}\text { 1. Professional Translator } \\
\text { 2. Intensive foreign language courses } \\
\text { 3. Management of state municipal and corporate procurement } \\
\text { 4. Modern aspects of military training in educational institutions of higher education of the } \\
\text { Russian Federation } \\
\text { 5. Occupational Safety Specialist } \\
\text { 6. Personnel Management } \\
\text { 7. Construction Economics }\end{array}$ \\
\hline
\end{tabular}




\begin{tabular}{|c|c|}
\hline & $\begin{array}{l}\text { 8. Functional Controlling. Office by goals and key indicators } \\
\text { 9. Business Basics for Beginners } \\
\text { 10. Ecology and environmental safety } \\
\text { 11. Standardization and certification } \\
\text { 12. Anti-corruption } \\
\text { 13. Building a system of financial controlling and budgeting at the enterprise } \\
\text { 14. Production Specialist } \\
\text { 15. Head of construction organization }\end{array}$ \\
\hline 2019 & $\begin{array}{l}\text { 1. Business English in construction and property management } \\
\text { 2. Intensive foreign language courses } \\
\text { 3. Professional Translator } \\
\text { 4. Active learning technology and methods of teaching a foreign language in the context of } \\
\text { the implementation of the Federal State Educational Standard } \\
\text { 5. State and municipal government } \\
\text { 6. State and municipal procurement management } \\
\text { 7. Engineering and economics in the digital economy } \\
\text { 8. Functional controlling. Office of Goals and Key Indicators Technology Entrepreneurship } \\
\text { 9. Personnel Management } \\
\text { 10. Management in technical systems } \\
\text { 11. Innovation management } \\
\text { 12. Anti-corruption } \\
\text { 13. Web Design and Development } \\
\text { 14. CAD engineering design } \\
\text { 15. Design Draftsman (CAD Engineering Design Competency) } \\
\text { 16. Improving the management of the process of preparing and issuing project } \\
\text { documentation: level of the chief engineer (architect) of the project } \\
\text { 17. Philosophy: Theory and Methods of Teaching in an Educational Organization } \\
\text { 18. Innovative technologies in teaching philological sciences } \\
\text { Chemistry: Theory and Methods of Teaching in an Educational Organization } \\
\text { 19. Methods and teaching techniques in the format of academic disciplines in the field of } \\
\text { physical education and sports } \\
\text { 20. Further training for specialists in welding managers at facilities controlled by } \\
\text { Rostekhnadzor } \\
\text { 21. Fundamentals of CPD in the electronic information and educational environment } \\
\text { 22. Geography: theory and methods of teaching in an educational organization } \\
\text { 23. Ecology and environmental monitoring } \\
\text { 24. Ecology and nature management } \\
\text { 25. Land management and nature management } \\
\text { 26. Environmental Engineering } \\
\text { 27. Life safety and labor protection }\end{array}$ \\
\hline
\end{tabular}



28. First aid
29. Pre-trip medical examination
30. Rational nature management and environmental management
31 . Work in the $1 \mathrm{C}$ information system for financially responsible persons
32. Judicial merchandising and value examination (non-food goods)

\section{CONCLUSION}

Thus, at the current moment, we can distinguish the main stages of training specialists in the system of multilevel vocational education:

1. Higher education in the chosen technical or economic specialty with the possibility of parallel training on the basis of short and long courses;

2. Postgraduate training of specialists in short-term advanced training courses with the issuance of a standard certificate;

3. Introducing a public-private partnership system - attracting practitioners with the possibility of conducting classes at enterprises for the purposes of initial training and advanced training

4. Training specialists at the request of enterprises, taking into account the peculiarities of their activities and subsequent employment at the enterprises-customers of trained specialists;

5. The organization of periodic seminars, webinars and master classes, including online format on various pressing issues and areas with the involvement of leading experts;

Ensuring innovative character in the system of continuing education can be carried out through:

1. The creation of a coordinating council for the training of highly qualified personnel

2. Creation and development of innovative territorial production, scientific and educational clusters;

3. The development of a system for assessing the forecasted needs of the labor market for qualified personnel, taking into account socio-economic and migration factors;

4. Monitoring current and future needs of the labor market;

5. The development of financing mechanisms for educational institutions from various sources of financing;

6. The development of methods for the integrated training of highly qualified personnel in cooperation with VSTU;

7. Scientific and methodological support of specialist training system;

8. The creation of a resource integrated educational center on the basis of the Voronezh State University that provides multistage training of personnel, as well as promoting the development of in-house training to ensure continuing professional education of the population as a means of ensuring current and future socioeconomic needs for qualified personnel;

9. Assignment of basic enterprises to educational institutions;

10. The formation of a system of contractual relations between employers and educational institutions on the issues of employment of graduates, as well as material and technical equipment

\section{REFERENCE LIST}

1. https://site.bilet.worldskills.ru/

2. Varlamova D., Sudakov D. (2020).Atlas of new professions 3.0. M.: Intellectual Literature, p. 456.

3. Vorotyntseva A.V., Belousov V.E., Komyshova L.N., Andrunina Ya.A. (2019). Introducing the VSTU multidisciplinary education system Economics in the investment and construction complex and housing and communal services, No. 2 (17), pp. 89-95 
4. Davydova T.E., Avdeeva E.A. ,Vorotyntseva A.V. (2020). New trends in the field of labor and employment in the context of the spread of the digital .Economics and Entrepreneurship., No. 3 (116), pp. 147-150.

5. Dautova T. (2015). Additional professional education as a condition for the implementation of the concept of continuing education. VEGU Bulletin.. No. 1 (75), pp. 33-39.

6. Dmitriev N. (2010). Continuing education as the basis for the formation of a regional system of continuing professional education . Bulletin of Tula State University. Humanitarian sciences. No. 2, pp. 467-473

7. Kalimullin A., Shaydullina A. (2015). Diversification of integration models of education, science and production in a continuous system of professional education. Education and self-development. No. 1 (43), pp. 105-113

8. Noskova T., Pavlova T., Yakovleva O. (2016).Analysis of domestic and foreign approaches to building advanced educational practices in the electronic network environment. Integration of education, Vol. 20. No. 4 (85), pp. 456-467.

9. Skvortsov V. (2017). Continuing education as the basis of modern scientific . Bulletin of the Leningrad State University A. Pushkin. No 2, pp. 157-161.

10. Petrovsky A., Smirnova J. (2018). Formation of professional competencies of students in the context of project activities. Karelian scientific journal, Vol. 7. No. 1 (22), pp. 69-72.

11. Pokornaya I., Titorenko S., Ovsyannikova A (2019). Some issues of improving the training of masters in the field of $04.04,01$ teacher education under the program "Mathematical education". Prospects for science and education, .No 3 (39), pp. 184-195

12. Titorenko S., Pokornaya I., Ovsyannikova A. (2019). Methodological features of the use of complex tasks as a means of training future mathematics teachers. Bulletin of the Voronezh State Pedagogical University, No 2 (283), pp. 58-62 .

13. Gorbunova N. Design and creation of an innovative educational environment of a higher educational institution. Problems of modern teacher education, No. 46-1, pp. 223-229 (2015).

14. https://cchgeu.ru/education/dop/

15. Sergeeva M. (2011). Continuing economic education in the conditions of parity of education and the economy in a renewed Russia. STAGE: economic theory, analysis, practice, No. 5, pp. 117-126.

16. Bukhtoyarov N.I., Belyaev A.N., Trishina T.V. (2016). Improving the quality of education of correspondence students using e-learning. Bulletin of the Voronezh State Agrarian University, No 3 (50), pp. 211-217.

17. Vorotyntseva A.V., Ovsyannikov A.S. (2015). Training of specialists in budgeting in the system of multi-level vocational education. Science, education, practice: problems of integration and the search for optimal solutions, pp. 57-59.

18. Semenov V.A., Ovsyannikov A.S., Vorotyntseva A.V. (2013).Formation of the innovative character of the system of continuing professional education in construction. Socio-economic problems of the modern labor market. Materials of the International scientific-practical conference, pp. 141-144.

19. https://akvobr.ru/vserossiiskii_mediaproekt_obrazovatelnii_marafon.html

20. https://minobrnauki.gov.ru/ru/documents/card/?id_4=672\&cat=/documents/docs 